\title{
Pensions on divorce in Ireland: law, practice and a way forward?
}

KATHRYN O'SULLIVAN

University of Limerick

\begin{abstract}
The importance of pensions as a source of family wealth has attracted increased attention during the first decades of the twenty-first century. In particular, ever-greater focus is now being placed in many jurisdictions on how the wealth beld in pensions is factored into financial remedies on marital breakdown. Notwithstanding that pension entitlements may also be some of the most valuable assets available for distribution on separation or divorce in Ireland, the Irish approach to pensions and pension adjustment orders on marital breakdown has attracted minimal comment or analysis. This article seeks to address this gap in the literature. It pulls together for the first time findings from various studies to investigate the prevalence of pension adjustment orders, specifically, in Irish divorce practice. Reflecting on these findings and the Supreme Court's recent 2019 judgment in F v M, it analyses the regime and considers a multifaceted approach to reform.
\end{abstract}

Key words: pension; ancillary relief; financial provision; reform

\section{Introduction}

The importance of pensions as a source of family wealth has attracted increased attention during the first decades of the twenty-first century. In particular, ever greater focus is now being placed in many jurisdictions on how the wealth held in pensions is factored into financial remedies on marital breakdown with an ever-expanding body of law reform reports, empirical research and academic commentary investigating the issue. ${ }^{1}$ In England and Wales, notwithstanding that '[p]ublic understanding and interest in pensions is

1 See Alan Brown, 'Pension Sharing in Scotland: General Principles in the Family Law (Scotland) Act 1985?' (2018) 40(1) Journal of Social Welfare and Family Law 104; New Zealand Law Commission, Dividing Relationship Property - Time for Change? (Issues Paper 41-2017, New Zealand Law Commission 2017) 286-89; Fumie Kumagai, 'Late-Life Divorce in Japan Revisited: Effects of the Old-Age Pension Division Scheme' (2014) Family Issues on Marriage, Divorce, and Older Adults in Japan 119; Grania Sheehan, April Chrzanowski and John Dewar, 'Superannuation and Divorce in Australia: An Evaluation of Post-Reform Practice and Settlement Outcomes' (2008) 22(2) International Journal of Law, Policy and the Family 206; British Columbia Law Institute, Pension Division on Marriage Breakdown: A Ten Year Review of Part 6 of the Family Relations Act (Report No 44-2006, BCLI 2006); Ministry of Justice, Family Law Act Explained (Part 6: Pensions) $<$ www2.gov.bc.ca/assets/gov/law-crime-and-justice/about-bc-justice-system/legislationpolicy/fla/part6.pdf>. For recent research in England and Wales, see below. 
generally weak', particular emphasis has been placed on pension-sharing on divorce with a number of comprehensive reports published on the issue in the past five years. ${ }^{2}$

In Ireland, the Office of the Pensions Ombudsman noted in 2015: 'Frequently, particularly where house property may be in negative equity, the pension entitlements may be one of the most valuable assets available for distribution on separation or divorce.' 3 Yet, despite this, the Irish approach to pensions and pension adjustment orders on marital breakdown has attracted minimal comment or analysis. ${ }^{4}$ It is apt, then, that the first reported Supreme Court judgment of 2019, Fv M, places the Irish approach to financial remedies on marital breakdown (known as 'ancillary relief provision' under Irish law), and pension adjustment orders in particular, under the spotlight. ${ }^{5}$

Part 1 outlines the historical context for the introduction of pension adjustment orders in Ireland and the key provisions contained in s 17 of the Family Law (Divorce) Act 1996. Part 2 then pulls together for the first time findings from various studies to investigate the prevalence of pension adjustment orders in Irish divorce practice. Part 3 summarises the Supreme Court's 2019 judgment in Fv M, before Part 4 analyses the weaknesses of the regime in light of the decision and the various studies considered. Part 5 concludes by considering a multifaceted approach to reform including the need for legislative intervention, judicial engagement and the development of greater education and support initiatives for practitioners, specialists and judges alike.

\section{Pension adjustments orders under the Family Law (Divorce) Act 1996}

\section{THE EMERGENCE OF PENSION ADJUSTMENT ORDERS IN IRELAND}

In 1992, the Irish government published its White Paper on Marital Breakdown. ${ }^{6}$ The White Paper sought to address various implications of legislating for the introduction of a remedy of divorce. ${ }^{7}$ However, as then Minister for Justice Máire Geoghegan-Quinn observed, the paper did not 'gloss over the fact' that there remained a difficulty 'in at least

2 Hilary Woodward (with Mark Sefton), Pensions on Divorce: An Empirical Study (Cardiff University 2014) $<$ https://orca-mwe.cf.ac.uk/56702/1/14\%2002\%2024\%20KF\%20final.pdf >. Building on the findings of this research, Pension Advisory Group, A Guide to the Treatment of Pensions on Divorce (Nuffield Foundation 2019) was recently produced, see <www.nuffieldfoundation.org/pensions-divorce-interdisciplinary-workinggroup $>$. See also Joanna Miles and Emma Hitchings, 'Financial Remedy Outcomes on Divorce in England and Wales: Not a "Meal Ticket for Life" (2018) 31(2) Australian Journal of Family Law 43; Emma Hitchings and Joanna Miles, 'Meal Tickets for Life? The Need for Evidence-Based Evaluation of Financial Remedies Law' (2018) 48 Family Law 993; Emma Hitchings, Joanna Miles and Hilary Woodward, Assembling the Jigsaw Purzle: Understanding Financial Settlement on Divorce (Nuffield Foundation 2013).

3 Office of the Pensions Ombudsman, Annual Report (Office of the Pensions Ombudsman 2015) 13 <www.fspo.ie/documents/archives-pensions/Annual\%20Report\%202015.pdf>. There has been no reference to divorce in any annual report since then. Note, since 2017, the role of Pensions Ombudsman has been subsumed within that of the Financial Services and Pensions Ombudsman.

4 The most comprehensive family law analysis of pensions and pension adjustment orders is Laura Cahill and Sonya Dixon, Pensions: A Handbook for the Family Law Practitioner (Bloomsbury 2015). See also Louise Crowley, Family Law (Round Hall 2013) 11-101ff. Note, the practice around pensions on marital breakdown was peripherally noted in empirical research, including Roisin O'Shea, Judicial Separation and Divorce in the Circuit Court (PhD Thesis, Waterford Institute of Technology 2014); Lucy-Ann Buckley, 'Irish Matrimonial Property Division in Practice: A Case Study' (2007) 21 International Journal of Law, Policy and the Family 48; Carol Coulter, Family Law in Practice: A Study of Cases in the Circuit Court (Clarus Press 2009).

5 [2019] IESC 1.

6 Department of Justice, White Paper on Marital Breakdown: A Review and Proposed Changes (Stationery Office 1992).

7 Cf the then ban on divorce formerly found in Article 41.3.2 of the Irish Constitution, Bunreacht na bÉreann. 
one area, namely, loss of pension following divorce'. ${ }^{8}$ Although the draft Divorce Bill it presented required a court when making a financial provision order to take account of the value to each of the parties to the marriage of any benefit, including a pension, which by reason of divorce one party would forego, the White Paper concluded that 'this might not constitute adequate protection in all cases'?

Reflecting on the experience in England and Wales, the White Paper noted that '[n]o means' had yet been discovered 'of dividing occupational pensions on divorce so as to mitigate the potential hardship involved'. ${ }^{0}$ While a 'number of solutions' had been canvassed in other 'neighbouring jurisdictions', they too had ultimately been rejected in those jurisdictions as 'unworkable or inappropriate'. 11 On the one hand, it noted that empowering the court to order that an occupational pension should be paid in whole or in part to a divorced spouse could present 'many problems and could, in certain circumstances, cause grave hardship to a second or subsequent spouse'. ${ }^{12}$ On the other hand, providing an occupational pension which would accrue to successive wives in proportion to the length of each marriage' could give rise to 'complex problems in pension administration'. ${ }^{13}$ Although the White Paper concluded that the hardship involved in the loss of a prospective occupational pension could be met 'to some extent' by a secured maintenance order ${ }^{14}$ or by requiring the maintenance debtor to purchase an annuity for the other spouse to compensate for the loss of pension benefits, it was particularly concerned for those cases where divorced spouses had remained at home to care for the family, were too old to take up employment of a pensionable nature and had acquired no occupational pension rights in their own right. ${ }^{15}$ The White Paper thus recommended that where grave hardship might result, the court ought to be able to refuse to grant a decree of divorce. Notwithstanding that it was 'rarely invoked . . . and, apparently, even more rarely successful', it noted that such a grounds for refusal applied in England and Wales and would provide an 'important protection' for those who might suffer such hardship. ${ }^{16}$

Although the legislature subsequently adopted the former recommendation (that when making ancillary relief provision the court ought to take account of the value of

8 See Friday, 26 March 1993 Dáil Éireann debate on the White Paper on Marital Breakdown <www.oireachtas.ie/ga/debates/debate/dail/1993-03-26/3/>. Although the White Paper was prepared by the Department of Justice, responsibility for the reform of family law was subsequently transferred to the then newly established Department of Equality and Law Reform.

9 Department of Justice (n 6) at [13.5].

10 Ibid at [13.6]. Pension-sharing powers were introduced in England and Wales in 2000, see below for more.

11 Ibid at [13.7].

12 Ibid.

13 Ibid.

14 Which could continue to be paid after the death of the maintenance debtor

15 Department of Justice (n 6) at [13.8]-[13.9]. Alternatively it noted a property adjustment order "may provide sufficient compensation' for the loss.

16 Ibid at [13.6]. Note this was separate and distinct from a recommendation that 'proper provision' ought to be a pre-condition to a decree of divorce. S 5 of the Matrimonial Causes Act 1973 in England and Wales continues to provide for the refusal of a decree of divorce in five-year separation cases on the grounds of grave hardship to respondent. However, a recent study of defended divorce cases highlighted how little recourse there is to the provision. Observing the 'extremely high bar' s 5 sets, Liz Trinder and Mark Sefton, No Contest: Defended Divorce in England and Wales (Nuffield Foundation 2018) 79 note: 'The only area where respondents initially had some limited success with a hardship defence was in relation to the loss of pension rights. However, the introduction of pension-sharing following the Welfare Reform and Pensions Act 1999 has made even that defence extremely unlikely.' 
any benefit, including a pension, which by reason of divorce a party would forego), ${ }^{17}$ it did not accept the latter recommendation permitting a court to refuse to make a decree of divorce. Rather, drawing on the expertise of the Pensions Board and 'certain key figures in the pensions industry', 18 the legislature chose to empower the Irish courts to redistribute wealth held in pensions directly. Notwithstanding the White Paper's doubts about the viability of such reform, so-called 'pension adjustment orders', considered below, were introduced on judicial separation and divorce through the Family Law Act 1995 and the Family Law (Divorce) Act 1996. ${ }^{19}$

\section{PENSION ADJUSTMENT ORDERS ON DIVORCE IN IRELAND}

Part III of the Family Law (Divorce) Act 1996 places considerable discretion in the hands of the judiciary which is enjoined to effect an equitable redistribution of property that 'shall ensure' that, as constitutionally mandated by Article 41.3.2 and as a pre-condition to the award of a decree of divorce, 'proper provision' is made for a dependent spouse and children. ${ }^{20}$ Among the orders available to achieve this end, s 17 of the 1996 Act empowers the courts to make pension adjustment orders. ${ }^{21}$

For the purposes of s 17, pensions are divided into two categories: 'retirement benefits' and 'contingent benefits'. ${ }^{22}$ Retirement benefits are defined as 'all benefits (other than contingent benefits) payable' under a scheme. ${ }^{23}$ Retirement benefits are thus benefits payable post-retirement and usually include a lump-sum payment on retirement and a pension paid to the scheme member, or to the member's spouse and/or dependants, should the member die post-retirement. ${ }^{24}$ Contingent benefits are benefits payable on the occurrence of a particular contingency and are generally payable if the member dies while employed and still a member of the scheme. ${ }^{25}$ Similar to retirement benefits, contingent benefits include a lump-sum payment and a pension payable to the member's spouse and/or dependants. ${ }^{26}$ Pursuant to s 17(3), an application for a pension adjustment order

17 S 20(2)(k) of the Family Law (Divorce) Act 1996, see below.

18 Per the Minister for Equality and Law Reform, Mr Taylor, Thursday 27 June 1996, Dáil Éireann debate on the Family Law (Divorce) Bill, 1996: Second Stage < https://www.oireachtas.ie/en/debates/debate/dail/199606-27/3/>. See also Wednesday 23 March 1994 Dáil Éireann debate on the Family Law Bill, 1994: Second Stage (Resumed) < https://www.oireachtas.ie/en/debates/debate/dail/1994-03-23/4/>.

19 The situations in which such orders can be made have since been extended. For civil partners, see s 121 of the Civil Partnership and Certain Rights and Obligations of Cohabitants Act 2010. For cohabitants, see s 187 of the 2010 Act. Note also the role of the Pension Schemes (Family Law) Regulations 1997 (SI 107/1997), see Cahill and Dixon (n 4) $77 \mathrm{ff}$.

20 See s 20 of the Family Law (Divorce) Act 1996. Whether this lofty goal is achieved in all cases remains doubtful, however, see Kathryn O'Sullivan, 'Rethinking Ancillary Relief on Divorce in Ireland: The Challenges and Opportunities' (2016) 36(1) Legal Studies 111.

21 Note s 12 of the 1995 Act governs pension adjustment orders on judicial separation and is almost identical to s 17 of the 1996 Act. For ease, reference is only made here to the divorce provisions. As a result of the passing of the referendum on the Thirty-Eighth Amendment to the Constitution in May 2019 the wait period for a divorce is expected to be reduced from four years to two. This will likely reduce the number of judicial separations significantly with spouses likely to proceed directly for a divorce.

22 Although Cahill and Dixon (n 4) 36 note a 'very wide' definition of 'pension scheme' is taken in Irish family law legislation, the issue has nonetheless given rise to some difficulties, see for example $D v D$ [2015] IESC 16.

23 S 17(1) of the 1996 Act.

24 See Cahill and Dixon (n 4) 51-55.

$25 \mathrm{~S} 17(1)$ of the 1996 Act. It may be referred to as a 'death in service' benefit.

26 Cahill and Dixon (n 4) 55-56. Donagh McGowan and Tommy Nielsen, 'Making the Adjustment' (June 2012) Law Society Gazette 42 note there are two types of pension benefit in Ireland: defined benefit (DB) and defined contribution (DC) schemes. 
in relation to a contingent benefit, specifically, must be made within one year after the granting of the decree of divorce. By contrast, an application for such an order in respect of a retirement benefit can be made at the time of the granting of the decree of divorce or at any time thereafter during the lifetime of the member spouse. ${ }^{27}$

Where a court determines that a pension adjustment order is warranted, it may make an order stating that a percentage of the whole or part of a benefit ought to be paid directly to the other spouse (or to another person for the benefit of a dependent member of the family) in a process known as 'earmarking'. ${ }^{28}$ Alternatively, a spouse in whose favour an order is made may wish to use the 'pension-splitting' provisions of s 17(4), whereby a percentage of a retirement benefit which has been designated for them is valued and is then used to provide a separate pension for that spouse. ${ }^{29}$

To determine the value of the retirement benefits to be earmarked or split, the court has to identify the period of 'reckonable service'. ${ }^{30}$ 'Reckonable service' is defined as 'service in relevant employment during membership of any scheme': in effect, the period during which the retirement benefits were earned. ${ }^{31}$ In keeping with the general ethos of the legislation not to characterise assets as marital or non-marital, the Act does not require that in determining the period of reckonable service regard be had to the length of time during which the member was simultaneously a member of the pension scheme and was married (or in a relationship) with the non-member spouse. ${ }^{32}$ Despite this, the period of the marriage is 'usually' the period of 'reckonable service', with cohabitation prior to marriage 'sometimes taken into account'. ${ }^{33}$ The court then determines the relevant percentage of the retirement benefits accrued during the relevant period to be allocated to the applicant spouse. ${ }^{34}$ Once accruing, the amount payable to the person in whose favour a pension adjustment order based on earmarking, specifically, is made is known as the 'designated benefit'. ${ }^{35}$

In determining whether or not to make a pension adjustment order, and, if so, the percentage of the pension to be earmarked or split, the court must have regard to a

27 See s 17(2) of the 1996 Act.

28 Ibid. See Cahill and Dixon (n 4) 69-70. Note an application must be made for a pension adjustment order as a court cannot make such an order of its own motion. Cahill and Dixon (ibid 52) highlight the 'ambiguity' in s 17(2) which states that an order for retirement benefits can be made 'to either of the following, as the court may determine, that is to say-(a) the other spouse and, in the case of the death of that spouse, his or her personal representative, and (b) such person as may be specified in the order for the benefit of a person who is, and for so long only as he or she remains, a dependent member of the family ...' (emphasis added).

29 See Cahill and Dixon (n 4) 70-72. Note pension-splitting is only available in relation to retirement benefits.

30 S 17(2)(b)(i) of the 1996 Act.

31 S 17(1) of the 1996 Act.

32 Note, however, that the duration of the marriage is a factor to be considered under s 20(d) of the 1996 Act.

33 Cahill and Dixon (n 4) 37. While this does appear to contradict the wording of s 17(1), it is arguable that, in confining the period of 'reckonable service' to the period when the spouse was a member of the scheme and was married (or cohabiting), the courts are implicitly recognising a partnership- or contribution-based basis for sharing in Irish divorce law. See also the decision in JCN $v$ RTN (HC 15 January 1999), discussed in Frank Martin, 'Prohibition to Approval: The Limitations of the "No Clean Break" Divorce Regime in the Republic of Ireland' (2002) 16(2) International Journal of Law, Policy and the Family 223, 241; and TT v TT (HC 26 June 2002). Note the relevant period cannot extend beyond the granting of the decree of judicial separation or divorce.

34 See s 17(2)(b)(ii) of the 1996 Act. For contingent benefits, only the percentage to be paid to the non-member must be specified in the pension adjustment order (no period of reckonable service is required): s 17(3).

35 S 17(1) of the 1996 Act. For more, see Cahill and Dixon (n 4) 38, 68-70. This terminology is not used typically where the earmarked benefits to be paid to the non-member spouse are used to create a separate pension using the pension-splitting provisions of s 17(4) of the 1996 Act. 
non-exhaustive list of statutory factors enumerated in s 20 of the 1996 Act. These factors include 'the income, earning capacity, property and other financial resources which each of the spouses concerned has or is likely to have in the foreseeable future'36 as well as 'the value to each of the spouses of any benefit (for example, a benefit under a pension scheme) which by reason of the decree of divorce concerned, that spouse will forfeit the opportunity or possibility of acquiring, ${ }^{37}$ The legislation also, however, makes it clear that a pension adjustment order exists solely as a last resort. Pursuant to s 17(23)(b), the court is required to consider whether "proper provision, having regard to the circumstances, exists or can be made for the spouse concerned or the dependent member of the family concerned' by virtue of other order of the court, for example, by property adjustment order or financial compensation order. ${ }^{38}$ Finally, although s 22 of the 1996 Act permits parties to seek a variation of pension adjustments ordered in relation to a retirement benefit, ${ }^{39}$ under s $17(26)$ the ability to seek such variation may be restricted 'to a specified extent' or excluded entirely by order of the court, commonly known as a 'blocking order'.

\section{Pension coverage and pension adjustment orders in Irish divorce practice}

\section{Pension coverage IN IRELAND}

According to the Central Statistics Office, in Quarter 3 of 2018, over half (56.3\%) of all workers aged between 20 and 69 years had private pension coverage involving occupational pension coverage (from current or previous employments) and/or personal pension coverage. ${ }^{40}$ Pension coverage remained lowest among younger ${ }^{41}$ and part-time

36 S 20(2)(a) of the 1996 Act.

37 S 20(2)(k) of the 1996 Act. Note, this factor is taken to refer to any widow(er)'s benefits for which the now ex-spouse will no longer be eligible owing to the loss of marital status.

38 In MP $v$ AP (2005) IEHC 326 (unreported), O’Higgins $\mathrm{J}$ in the High Court quoted from the guidance notes issued by the Pensions Board in relation to s 17(23)(b) which stated: 'The legislation requires the court to consider the question of whether adequate and reasonable financial provision exists or can be made by means of any other orders that are available under the Act, prior to the making of a pension adjustment order.' Consequently, the court held that it 'must consider whether provision can be made by recourse to other orders available, but it is not precluded from making an order under section $17(23)(\mathrm{b}) \ldots$ if there is good reason to do so.' Notwithstanding this, s 17(23(b) has been widely interpreted as limiting the ordering of pension adjustments to situations where no alternative orders are suitable. As Lucy-Ann Buckley, 'Irish Matrimonial Property Division in Practice: A Case Study' (2007) 21 International Journal of Law, Policy and the Family 48, 64 highlights, 'the legislation implicitly suggested that the court should consider a pension adjustment order as a last resort'. Crowley (n 4) 633-34 concludes likewise. This approach, which places a clear emphasis on offsetting, appears highly questionable particularly when viewed in light of the challenges involved in offsetting pension wealth highlighted by the Pension Advisory Group (n 2) in England and Wales. See below for more. S 17(23)(a) of the 1996 Act also states that the court 'shall not make a pension adjustment order in favour of a spouse who has remarried'.

39 It is 'widely accepted' that contingent orders may not be varied under the 1996 Act given the wording of s 22(1)(h), see Cahill and Dixon (n 4) 57. However, they expand at 57 and 75-76 on one way this may technically be possible.

40 As regards personal pension coverage, this included those where payments has been deferred for a period of time or were being drawn down by the pension holder. Note, these results were derived from a pensions survey of workers which was included in the Labour Force Survey in Quarter 3 (July-September) of 2018. The survey did not measure pensions provided through the State Social Welfare Scheme. See <www.cso.ie/en/releasesandpublications/er/pens/pensioncoverage2018/>.

41 In Quarter 3 2018, just over four out of every $10(41.5 \%)$ workers aged 25 to 34 years reported having a pension (ibid). 
workers. $^{42}$ The highest figures were recorded among full-time workers ${ }^{43}$ and, in particular, among workers aged 45-54 years where total pension coverage exceeded 70 per cent. ${ }^{44}$ Although the 2018 statistics did not elaborate on the difference in coverage between men and women, a strong gendered dimension in Irish private pension coverage has been identified in recent years. The Irish Longitudinal Study on Ageing, Fifty Plus in Ireland 2011, found that women in the jurisdiction were significantly less likely to be covered by occupational or private pension schemes. ${ }^{45}$ While only 20 per cent of men at work were not covered by an occupational, Personal Retirement Savings Account or private pension scheme, this figure rose to 41 per cent among women. ${ }^{46}$ It appears the trend has largely continued. It was recently reported, based on a survey of more than one thousand people by Behaviour \& Attitudes on behalf of pension provider Aviva, that 'the number of women with private pensions coverage has remained stubbornly stable at about 37 per cent' over the last five years. ${ }^{47}$ While the difference in the average levels of retirement income of men and women may not be as great as originally feared (analysis of data from the 2011 longitudinal study suggested that the average income of male retirees was 58 per cent higher than that of female retirees), ${ }^{48}$ it also retains a strong gendered dimension. Recent data from the European Commission's 2018 Report on Equality between Women and Men in the EU suggests a retired woman living in Ireland receives approximately 30 per cent less retirement income than her male counterpart. ${ }^{49}$

\section{DEALING WITH PENSIONS: PENSION ADJUSTMENTS, OFFSETTING AND 'NIL' ORDERS}

In determining how to take account of this wealth held in pension funds in ancillary relief proceedings on divorce, the courts have two main approaches. First, a court may use the detailed machinery of s 17 of the 1996 Act discussed above. However, as the Pensions Authority Guidance Notes highlight, this is not the most common approach. Rather, the Authority explains, 'the Court will try to avoid making a pension adjustment order and instead take account of pension benefits by means of one of the other types of order'. ${ }^{50}$

42 Of these, only $36 \%$ had private pension coverage (ibid).

$4361.4 \%$ of such workers received such protection (ibid).

44 Total pension coverage for this cohort was recorded as 70.9\% (ibid). 55-69 year-olds recorded $68.2 \%$ coverage.

45 The Irish Longitudinal Study on Ageing, Fifty Plus in Ireland $2011 \quad 233-34$ <https://www.ucd.ie/issda/t4media/0053-01_TILDA_Master_First_Findings_Report_2011.pdf >. See also Kathryn O'Sullivan, 'Ancillary Relief and Private Ordering: The Vulnerability of Financially Weaker Spouses' (2016) 19(1) Irish Journal of Family Law 3-6.

46 The Irish Longitudinal Study on Ageing (n 45). See also National Women's Council of Ireland, Pensions: What Women Want (National Women's Council of Ireland 2008).

47 See Dominic Coyle, 'Women Continue to Snub Pensions as a Financial Priority, Study Finds' Irish Times (Dublin, 25 February 2019).

48 Sanna Nivakoski and Alan Barrett, Supplementary Pensions and the Income of Ireland's Retirees (TILDA 2012) < https://tilda.tcd.ie/publications/reports/pdf/Report_PensionsIncome.pdf>.

49 See European Commission, Report on Equality between Women and Men (Publications Office of the European Union, 11 February 2019) $24<$ https://publications.europa.eu/en/publication-detail//publication/950dce57-6222-11e8-ab9c-01aa75ed71a1>. Although this may not create significant issues where spouses are still married, it heightens the importance of fair divorce settlements to ensure adequate retirement income for divorced wives.

50 Pensions Authority, Pension Provisions of the Family Law Act 1995, Family Law (Divorce) Act 1996 and Civil Partnership and Certain Rights and Obligations of Cohabitants Act 2010 (Pensions Authority 2015) 6 <www.pensionsauthority.ie/en/News_Press/News_Press_Archive/Guidance_Notes_on_Pension_Provisions_ of_Family_Law_Act_1995_Family_Law_Divorce_Act_1996_And_Civil_Partnership_And_Certain_Rights_ And_Obligations_Of_Cohabitants_Act_2010_Nov_2015_pdf $>$. Note similar findings were reported in England and Wales, see Hitchings et al (n 2); Woodward (with Sefton) (n 2). 
In this manner, and in line with s 17(23)(b), a court may take account of pension benefits by splitting other, non-pension assets, leaving the pension intact with the original member in a process commonly known as 'offsetting'. 51

Where such offset takes place, member spouses will usually wish to protect their pension against future claims under s 17. However, as a result of a lacuna in the 1996 Act, it is not possible to secure a blocking order under s 17(26) where no pension adjustment order has actually been made. It is equally not possible for a court to make a zero pension adjustment order and order that none of a member's pension benefits be awarded to a non-member spouse. Consequently, as the Pensions Authority explains:
... in practice if such an order [declaring that none of a member's pension benefits be given to a non-member spouse] is sought, the Court will rule that a very small percentage of benefits (e.g. $0.001 \%$ ) earned over a short period (usually 24 hours) be designated for the non-member spouse/civil partner. This results in a 'nil-order', with designated benefits so small that in practice the trustees do not comply with the order. ${ }^{52}$

The so-called 'blocking' provisions of the Irish legislation may then be used against this 'nil' order to prevent future applications for variation and thus future claims for a pension adjustment order.

In addition to creating undesirable levels of complexity and bureaucracy in the ancillary relief process, the use of nil orders in this way has the effect of potentially skewing quantitative empirical findings or statistics seeking to determine the frequency of substantive pension adjustment orders in Ireland. Notwithstanding this, however, it is interesting to consider the findings of research in the field over the past almost 20 years.

\section{PENSIONS IN IRISH DIVORCE PRACTICE}

In 2002, Lucy-Ann Buckley conducted one of the first significant (albeit small-scale) post-divorce referendum empirical studies of Irish ancillary relief provision. She analysed 89 case file questionnaires completed by 44 family law solicitors on their most recently completed divorce or judicial separation file. ${ }^{53}$ In considering the outcomes in consensual cases, she found that wives were 'almost the exclusive beneficiaries of pension adjustment orders', although she also noted that these were 'not particularly common, as in many cases there was no pension to be adjusted'. ${ }^{4}$ Where such orders were made, the proportion of the pension benefit transferred was unknown and the possibility that these may have included nil orders was highlighted. ${ }^{55}$ In relation to non-consensual cases, she found pension adjustment orders were 'less common' but attributed this to an apparent 'dearth of pensions, at least in divorce cases'. ${ }^{56}$ Where presented, she noted the orders again 'mostly favoured the wife'. ${ }^{57}$ Reflecting on her findings, she concluded:

It is hard to comment on the greater prevalence of pension orders in consent cases, particularly as it is unclear how many of the orders were 'nil' orders, made

51 See Aoife Lavan, 'Pension Adjustment Orders: The Dangers of not Seeking Advice' (2016) 29(3) Irish Tax Institute Tax Review 122, 122.

52 Pensions Authority (n 50) 9. See also Cahill and Dixon (n 4) 56, 124.

53 Buckley ( $\mathrm{n}$ 4). Three-quarters of the questionnaires were completed by private practitioners and just over a quarter by Legal Aid practitioners.

54 Ibid 64.

55 Ibid 64. She added 'it must be remembered that "nil" orders are common'. Pension adjustment orders were less common in legal aid cases.

56 Ibid 66.

57 Ibid 66 . 
purely to invoke the 'blocking' provisions of the legislation. It is possible that parties in consensual cases are more inclined to share assets, but equally they may simply be more inclined to view pensions as negotiable assets, to be traded in return for other concessions. 58

Buckley's study also highlighted regional variations in the approach adopted to pension adjustment orders in both consensual and non-consensual cases ${ }^{59}$ and appeared to identify a correlation between the presence of dependent children and the likelihood of a pension transfer, with pension transfers more common in cases not involving dependent children. ${ }^{60}$ Finally, (and perhaps related to this latter finding) the study found that pension adjustment orders were 'least common' in medium-length marriages, those between 11 to 20 years. ${ }^{61}$

In 2009, Carol Coulter reported the findings of her empirical research conducted in the Irish Circuit Courts which saw her analyse 459 case files from October 2006 and attend court hearings throughout 2006-2007 in which 239 judicial separation and divorce cases were concluded. ${ }^{62}$ Given the high settlement rate noted, ${ }^{63}$ the outcomes of all cases, contested and consent, were analysed together. ${ }^{64}$ Reflecting on the outcomes recorded in the case files, she reported that '[o]nly a minority' of spouses used the 'sophisticated legislation' applied in Ireland to deal with the division of pensions. ${ }^{65}$ She found that, even in those cases, there was 'a significant proportion' who sought only 'nominal pension adjustment orders, preserving their pensions with the agreement of the other spouse'.66 Where such an approach was adopted, the pension could be 'offset against a greater share of the family home'. ${ }^{67}$ Although pension adjustment orders where a portion of the pension or the contingent benefit was allotted to the other spouse arose in 31.5 per cent of cases involving other assets, Coulter nevertheless concluded that there appeared to be a 'reluctance on the part of litigants to exercise their rights under the legislation'. ${ }^{68}$ Similar trends were identified in the hearings attended as part of the research. Again, she found that

58 Ibid 66-67.

59 Ibid 67-68. She found 'many types of ancillary property order' including pension adjustment orders 'were most common in cases heard in Cork'. The other centres considered were Dublin and Galway. She noted: 'Of course, much may depend on the resources of the parties, but the differences seemed sufficiently consistent to consider Cork judges likely to be more redistributive than judges in the other two venues'. In terms of consensual cases, 'far more' such cases included pension adjustments in Cork (in comparison to nonconsensual cases) while, despite the lower base in Galway, 'far less' included such orders there. Less divergence in approach between consensual and non-consensual cases was evident in Dublin.

60 Ibid 68-69.

61 Ibid 70.

62 Coulter (n 4). See also the associated Courts Service, Family Law Matters Series (Courts Service 2007-2009) <http://www.courts.ie/Courts.ie/library3.nsf/(WebFiles)/AF1984DCA46E944A802576AA003BC8BA/\$FI LE/Family\%20Law\%20Matters\%20Index\%20updated\%20Jan\%202010.pdf>.

63 On the basis of the case files reviewed, she noted $91 \%$ of cases were settled, see Coulter (n 4) 59. Although the methodology adopted for court attendance (which prioritised attendance at contested cases) resulted in an under-representation of settlements, as noted at 72 , she surmised that a similarly high settlement rate would likely have been present in the general caseload dealt with by the courts.

64 Ibid 24, Coulter noted that cases that were settled and did not require court adjudication 'were filed in court records as the granting of a decree of divorce or judicial separation, many with minimal court orders other than the extinguishing of succession orders . . . but where the terms of the settlement were usually received and made rules of court'.

65 Ibid 65.

66 Ibid. Nominal pension orders were made in $12 \%$ of all cases and $25 \%$ of cases with other assets.

67 Ibid.

68 Ibid. It was not stated in what percentage of all cases such pension orders were made. 
pensions were 'rarely divided' although 'sometimes' orders were made in lieu of a pension adjustment order 'including a disproportionate allocation of interest in the family home'. ${ }^{69}$

In the most recent study undertaken, Roisin O' Shea observed 1087 unique cases between October 2008-February 2012 in the eight Irish Circuit Courts and analysed 40 case files. ${ }^{70}$ Seemingly reflecting the changed economic climate, she found pensions were often the "primary "assets" in the marital pot' as the family home and other properties often had 'little equity or were in negative equity'. ${ }^{71}$ In contested cases, she reported 'the approach of the court was to put [pensions] into the marital pot for a division of assets on a $50 / 50$ basis'. ${ }^{72}$ Whether this division resulted in the use of pension adjustment orders or saw the value reflected in a larger property adjustment or compensation order was not clear, nor was the adequacy of any arrangements reached.

Finally, it would be remiss not to consider official Courts Service statistics which were available up until to 2012 and which may also provide some insights. According to the Annual Report for 2012, pension adjustment orders were only made in 19 per cent of cases where a divorce was granted, down from 39 per cent in 2011 - a seemingly inexplicable 50 per cent drop. ${ }^{73}$ Pension adjustment orders were made in 53 per cent of cases where a judicial separation was granted, however, slightly down from 55 per cent in $2011 .{ }^{74}$ While these statistics appear to suggest pension adjustment orders play an important role in ancillary relief provision in Ireland, particularly on judicial separation, it remains unclear how many of these orders represented so-called nil orders or how the value held in pensions was accounted for in the provision made. ${ }^{75}$

\section{Pension adjustments in the spotlight: $F$ v $M$ [2019] IESC 1}

Whatever the lack of clarity as to the frequency of substantive (rather than nil) pension adjustment orders, such orders are coming under increasing scrutiny in the Irish Superior Courts. The most recent addition to the jurisprudence is the 2019 Supreme Court decision of $F \cup M .^{76}$

In January 2013, Abbott $\mathrm{J}$ in the High Court granted a divorce to the parties, $\mathrm{F}$ and M. Ancillary to this decree, the court made a number of orders regulating the financial

69 Ibid 105. This trend has also been identified in England and Wales, see Pension Advisory Group (n 2) 34.

70 O'Shea (n 4). It appears the outcomes to which the research refers were from a mixture of consent cases (with separation agreements often being made a rule of court) and contested cases where the adjudication of the court was required. The precise proportion of cases requiring adjudication was unclear.

71 Ibid.

72 Ibid 71. Note this observation seems to have related to judicial separation cases.

73 There were 543 pension adjustment orders made on divorce in 2012 and 2892 divorces granted. There were 1183 pension adjustment orders made on divorce in 2011 and 3005 divorces granted. See Courts Service Annual Report for 2012 (Courts Service, 21 June2012) <http://courts.ie/Courts.ie/library3.nsf/(WebFiles)/87BE463114EF96FF80257BA20033953B/\$FILE/Courts\%2 0Service $\% 20$ Annual $\% 20$ Report $\% 202012$.pdf $>$.

74 There were 457 pension adjustment orders made on judicial separation in 2012 and 858 judicial separations granted. There were 562 pension adjustment orders made on judicial separation in 2011 and 1029 judicial separations granted. See ibid.

75 It cannot be said definitively why the rate is so much higher on judicial separation than on divorce. One theory may be that parties wish to resolve practical issues such as the ownership of the family home at this initial stage (rather than waiting a further two to three years for a divorce to be finalised) and may in this context be agreeing to 'nil' pension adjustments orders on judicial separation as a form of offset. As noted above, however, this trend is likely to change when the wait period for divorce is shortened.

76 See (n 5). 
relationship between the parties. ${ }^{77}$ Among these was a pension adjustment order which awarded the respondent wife 80 per cent of the appellant's defined benefit pension fund, a fund which was valued at approximately $€ 800,000 .{ }^{78}$ The appellant husband appealed this distribution to the Supreme Court. The shortcomings in the key provisions of s 17 of the 1996 Act governing pension adjustment orders identified above were not the focus of the appeal. Rather, the appeal centred on the fundamental appropriateness or otherwise of the High Court's 80/20 division of the applicant's pension fund in favour of his former spouse which he claimed was 'over generous'. ${ }^{79}$

Significantly, by the time the full appeal was heard in January 2019, various distributions made on foot of interim pension adjustment orders had significantly reduced the overall fund remaining. First, in April 2013, the Supreme Court directed that, notwithstanding the appeal, the respondent wife was immediately to receive 40 per cent of the total value of the fund, half of the 80 per cent share which she was awarded in the High Court. ${ }^{80}$ Second, in July 2018, the appellant sought and received access to his 20 per cent share (which now represented 33.33 per cent of the remaining fund). ${ }^{81}$ As a result, by the time the judgment in the much delayed full appeal was delivered, only 40 per cent of the original fund remained undistributed, now worth $€ 380,000$.

Justice MacMenamin delivered the Supreme Court's judgment. Reflecting on the High Court's distribution - and no doubt echoing the sentiments of the applicant husband MacMenamin J admitted it was 'not entirely clear why Abbott J. arrived at the apportionment of $80 \%$ of the pension fund to the wife and $20 \%$ to the husband'. ${ }^{82}$ Although he noted that the duty of the Supreme Court, in general, 'is to seek to identify whether the High Court judge erred in principle in making the award', the court was nonetheless obliged to consider the parties' circumstances such as they exist at the time of the hearing. ${ }^{83}$ While the position of both parties had worsened since 2013, the Supreme Court found that the respondent [wife]'s situation had 'deteriorated more'. ${ }^{84}$ Particular attention was placed on her accommodation needs: 'While seeking to be fair to both sides, the more weighty factor identified, that is living accommodation, requires the Court to lean more towards the respondent than the appellant. ${ }^{95}$ MacMenamin $\mathrm{J}$ for the

$77 F v M$ (HC, 25 January 2013). Although the couple had separated since 2000, they only secured a decree of divorce in January 2013. For an overview of the history of the marriage and earlier litigation, see [2011] IEHC 559. Note, separate to the pension, it appears that following the order for judicial separation in 2002, the husband retained the right to live in the family home while the wife received a $€ 250,000$ lump sum and maintenance. The home and the pension appear to have been the most significant assets. Given the amount of litigation (much of which was unreported) and the many amendments made to various orders, however, it is not possible to describe or comment on the overall financial provision made in the case.

78 As estimated in $F v M$ (n 5) at [18].

79 Ibid at [5].

80 F v M (SC, 19 April 2013). In April 2013, the appellant had applied to the Supreme Court for a stay on the High Court order. The Supreme Court refused the stay and ordered that the respondent wife immediately receive half of her award as noted. However, pursuant to s 17(20) of the 1996 Act, the court did order that the trustees of the fund were not to disperse any of the remaining entitlements of the appellant $(60 \%)$ in the fund pending further order of the court. Note, the respondent wife encashed her $40 \%$ of the fund towards the end of 2014 as noted at $F v M$ (n 5) at [10]

81 This order was made by Irvine $\mathrm{J}$ in the Court of Appeal.

$82 F v M(\mathrm{n} 5)$ at [30].

83 Ibid at [34] the court noted it felt 'one cannot ignore the realities as they appear as of now'.

84 Ibid at [33]. By the time of the 2019 appeal, the wife was living abroad in the home of a friend and wished to return to Ireland. Note also that the couple had two children who, it was explained at [14], 'are now adults and are successfully making their way in the world'. However, somewhat confusingly, it was later remarked at [32] in relation to the husband that it was 'to his credit that he is taking care of one child'.

85 Ibid at [34]. Note accommodation needs are a factor listed in s 20(2)(j) of the 1996 Act. 
Supreme Court thus directed that the respondent wife receive 75 per cent of the balance of the fund with the appellant receiving the remaining 25 per cent. ${ }^{86}$ The end result therefore was that the wife received $70 \%$, rather than $80 \%$, of the pension.

\section{Shortcomings of the Irish approach identified}

It is clear from the case law and the various research studies analysed above that there are numerous difficulties with the way in which wealth held in pensions is addressed on divorce in Ireland.

First, at a fundamental level, $F v M$ vividly exemplifies the shortcomings, not only of the approach adopted to pension adjustment orders, but also the wider shortcomings of the highly discretionary equitable redistribution regime applied on marital breakdown in Ireland. In the absence of accurate data on the overall financial provision ordered between the parties since 2002, as well as information on their precise financial position when such orders were made, it is not possible to comment on the overall fairness of the orders made in either the 2013 or 2019 litigation. In this context, the uncertainty and lack of consistency inherent in the regime comes to the fore. Despite not explicitly saying so, it would appear the Supreme Court felt the High Court's 80/20 division of the applicant husband's pension fund in favour of the respondent wife was indeed 'over generous' - if not exceedingly so. Although, on one hand, the Supreme Court acknowledged that the respondent wife's situation had deteriorated more than the applicant husband's since 2013 with the court inclined to 'lean more towards the respondent', in allowing the appeal, the court significantly reduced the provision made for her ${ }^{87}$ - a fact which received little attention in the judgment or the associated media commentary. ${ }^{88}$ Viewed in percentage terms, a 10 per cent redistribution may not appear overly worthy of comment. However, when considered from the perspective of the applicant husband, this redistribution had a significant positive impact. In awarding him a 25 per cent share in the undistributed portion of the pension fund, his overall share of the entire pension effectively jumped by 50 per cent from 20 per cent to 30 per cent. ${ }^{89}$ At the time of the hearing, this increase saw the applicant benefit from a redistribution back to him approximately equivalent to an additional $€ 95,000.90$

Notwithstanding that an ancillary relief system founded on equitable redistribution will invariably sacrifice consistency in the pursuit of fairness in an individual case, where there is such a difference in opinion as to what the fairest outcome would be (and with such significant practical implications for the parties concerned), ${ }^{91}$ serious questions have

86 Ibid. The court noted: 'While seeking to be fair to both sides, the more weighty factor identified, that is living accommodation, requires the Court to lean more towards the respondent than the appellant.' At [32]- [33], the court noted: 'The simple fact is that the appellant is fortunate in that lifetime accommodation is available to him. He has a source of income, albeit an attenuated one . . By contrast, the respondent has no home.' Note, how precisely the pension adjustment order was going to resolve the respondent wife's accommodation needs was not elucidated on by the court. Moreover, the tax implications should she wish to convert it into cash were not referenced in the judgment.

87 See below. While the wife was due to receive $€ 380,000$, this was reduced to $€ 285,000$ by the Supreme Court.

88 The decision received considerable media attention. See, for example, Mary Carolan, 'Judge Hopes Couple's Costly 16 Year Legal battle "Will Now End"' Irish Times (Dublin, 22 January 2019).

89 Despite initially arguing that he ought to be awarded $100 \%$ of the remaining balance of the fund, in oral submissions, the appellant asserted that the court should grant him $30 \%$ of the $40 \%$ of the fund which remained to be apportioned, see [25]. In upholding the appeal, the court ultimately awarded him $25 \%$.

90 This figure is reached having regard to [19] and tallies with values advanced in the Court of Appeal in 2018 as noted at $[10]$.

91 Bearing in mind the court seemed to adopt a more generous approach to the spouse given her deteriorating financial circumstances. 
to be raised as to the overall appropriateness of the regime. ${ }^{92}$ Without meaningful parameters on the exercise of judicial discretion in relation to pension adjustments and ancillary relief provision generally, and in the absence, as a bare minimum, of a clear judicial explanation of what is being awarded and why, ${ }^{93}$ an unacceptable level of inconsistency in outcomes is inevitable with knock-on effects. Whether seeking a pension adjustment order or hoping to reconfigure the overall provision made to take account of the wealth held in a pension, the absence of a starting point (such as a presumption of equal sharing) or other meaningful guiding principles makes it extremely difficult to predict the outcome of any litigation. ${ }^{94}$ This ambiguity over such a valuable asset invariably promotes disputes. ${ }^{95}$

While not addressed in $F v M$ or the empirical studies considered, questions may be asked as to how, in the first instance, pensions are approached, categorised and (in particular) valued in Ireland. ${ }^{96}$ Although reported judgments rarely elaborate on how a pension valuation has been reached, it is possible that in many cases, whether contested or consent, regard is simply had to the cash equivalent value notwithstanding the shortcomings that have been identified with the over-reliance on this approach. ${ }^{97}$ Irrespective of whether earmarking, pension-splitting or offsetting is preferred, the need to have an accurate, appropriate and transparent valuation of all pension assets remains central and the lack of clarity in this regard further exacerbates the ambiguity inherent in the Irish regime.

As well as encouraging disputes, the uncertainty of the law and lack of transparency in relation to valuations can also have a particularly negative impact on financially weaker spouses seeking to reach a settlement regarding pension-sharing - especially in a system tilted towards offsetting as the preferred treatment of pensions. As alluded to in Part 2, women appear especially vulnerable in this regard. ${ }^{98}$ The absence of a 'shadow of the

92 Rosemary Horgan, 'Editorial: A Decade of Divorce in Ireland' (2007) 10(1) Irish Journal of Family Law 1 notes: 'the variation of treatment of pensions very much depends on judicial discretion' (emphasis added).

93 While undoubtedly complicated, it is to be regretted that the 2019 judgment in $F v M$ did not relate the full factual background and explain the pension adjustment order by reference to the rest of the settlement.

94 The only principle which can be said to exist is that 'proper provision' must be made. However, no further explanation as to what this might involve is set out in legislation. For a discussion of ancillary relief provision in Ireland, see O'Sullivan (n 20). Note, in England and Wales, pensions in 'need-based' and 'sharing' cases may be addressed differently, see Pension Advisory Group (n 2) Part 4.

95 In FvM (n 5) at [2], MacMenamin J said: 'It is an unfortunate fact that the subsequent lengthy hearings in this case, go back at least to the year 2002, have absorbed hundreds of thousands of Euro, which could have been used by the parties had the issues between them been resolved.'

96 See Pension Advisory Group (n 2) Parts 3 and 5. The valuation issue in particular appears heightened in Ireland in light of s 17(4) and section 17(23)(b). For more on the Irish approach to valuing pension assets, see Cahill and Dixon (n 4) 58-60. See also MD v ND [2015] IESC 16.

97 Pension Advisory Group (n 2) 20 and 21; Parts 6 and 7. It is suggested this possibility is increased in Ireland given the confusion noted among practitioners and specialists alike, see below for more.

98 While there appears to be a lack of data on the precise position of divorced retired women in Ireland, Áine Ní Léime and Nata Duvvury, Country Report: Ireland (Lives Working Paper 2019) 10 note on the basis of their research that: 'Older women who are divorced, widowed or single are less likely to be financially well off in retirement than are married women.' < https://livesnccr.ch/sites/default/files/pdf/publication/lives_wp_77.2_daisie_ireland_format_ah.pdf>.

Nata Duvvury, Áine Ní Léime and Aoife Callan, Older Women Workers' Access to Pensions: Vulnerabilities,

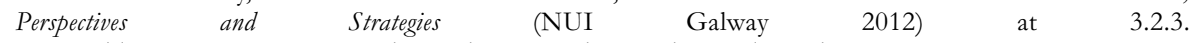
<https://aran.library.nuigalway.ie/xmlui/bitstream/handle/10379/3205/Older_Women_Workers_report _Aine.pdf? sequence $=1>$ also highlighted 'the extent to which many women are unprepared for the possible effects of loss of income, increased costs and potential loss of share in pension after divorce.' For more, see Nata Duvvury, Áine Ní Léime and Aoife Callan, 'Erosion of Pension Rights: Experiences of Older Women in Ireland' (2018) 5(3) European Journal of Cultural and Political Sociology 266. 
law' under which settlements in respect of pension-sharing can be negotiated ensures that the vulnerability of such spouses is heightened. In this context, vulnerable spouses appear especially reliant on judicial protection, as evidenced in research findings. Roisin O'Shea reported a consent divorce case where a wife who had no pension agreed to a nil pension adjustment order, preserving her husband's 'substantial pension' for his benefit, in circumstances where the primary provision for her appeared to be that she would receive a 50 per cent share of the net proceeds from the sale of the family home. Having reviewed the settlement reached, the court refused to rule on the terms. It held that 'proper provision' was not made and stated that the wife should have some entitlement to the pension in light of the length of the marriage. ${ }^{99}$ Whether such judicial protection will always be available, however, remains doubtful. ${ }^{100}$

Furthermore, a common finding across the various studies considered (which is corroborated by practitioners and referenced indirectly in $F v M$ ) is the high level of confusion and wariness with which pension adjustment orders, in particular, are associated. O'Shea reported: 'Where any question arose around pension adjustment orders, most of the judges deferred to counsel or sought clarification from counsel.'101 However, practitioners themselves appear equally fearful. Based on her research, Coulter suggested that pension adjustment orders were seen as 'overly complex by practitioners'. 102 Seemingly confirming this view, the Law Society's Pensions Law SubCommittee noted that it was 'generally recognised' that pensions adjustment orders were 'notoriously complex to draft and implement effectively'. ${ }^{103}$ Seeking to ameliorate the situation somewhat, it published a Template Pension Adjustment Order in January 2012. ${ }^{104}$ Notwithstanding the production of this template however, Laura Cahill and Sonya Dixon, authors of the leading family law practitioner guide on pensions, report that practitioners still tend to 'avoid dealing with pensions if possible'. ${ }^{105}$ They note that errors have 'the potential to have disastrous consequences' with these errors potentially not spotted for years. ${ }^{106}$

In light of the value of the asset, practitioners are therefore wary of engaging with pensions and exposing themselves to liability for a professional negligence claim. ${ }^{107}$ However, while they may feel the safer option is to seek to offset the value of the pension against other assets, the protection this provides may be illusory. As recently reported in

99 O'Shea (n 4) 84-85.

100 See O'Sullivan (n 20) 116-17.

101 O'Shea (n 4) 68. Note the case reported at 68 where, on making two pension adjustment orders, the court asked counsel if the orders were 'compatible'. It might have been anticipated that judicial expertise in relation to pension adjustment orders would improve in light of the Civil Partnership and Certain Rights and Obligations of Cohabitants Act 2010. It dictates that pension adjustment orders are to be considered before any property adjustment orders. However, the legislation appears to have generated relatively little case law.

102 Coulter (n 4) 105.

103 Template Pension Adjustment Order Explanatory Memorandum (Law Society of Ireland, 16 April 2019) <www.lawsociety.ie/globalassets/documents/committees/employment/pensions/pensionadjustmentorder.doc>.

104 Ibid. It noted: 'This template PAO is aimed at guiding members who are applying for such orders in Family Law matters. The template in primarily drafted from the perspective of a Defined Benefit Scheme and "nil pension adjustment order", but would require more comprehensive revisions if applied in respect of a Defined Contribution Scheme.'

105 Cahill and Dixon (n 4) 131.

106 Although recourse may be had to pensions specialists, they too appear cautious. Donagh McGowan and Tommy Nielsen (n 26) 42 note: 'Pension adjustment orders often cause difficulties for family law practitioners, but they are also a complex area for pension specialists.'

107 Ibid. 
England and Wales, ' $[\mathrm{w}]$ here there have been claims of negligence made against family lawyers in the field of pensions, it has overwhelmingly been in cases where offsetting has been the chosen remedy, not pension sharing'. 108 Specifically, it appears 'disadvantageous offsetting decisions' have been a 'significant source' of negligence actions. ${ }^{109}$ Although the issue has not attracted attention in Ireland to date, the potential for such negligence claims to be pursued in the jurisdiction appears tacit, particularly in light of the ambiguity surrounding valuations.

Finally, the complexity of the legislation and of pension funds themselves is particularly problematic for lay litigants. Legal representation and recourse to experts seems almost a prerequisite in seeking a pension adjustment order, yet the costs associated with such representation or expert input can be significant. Reflecting on the enormous costs allegedly charged by a pension trustee for his court appearance in $K v$ $M,{ }^{110}$ MacMenamin J noted 'whatever sympathy one might feel in relation to these costs ... the position is that neither this Court, nor the High Court, would have been in a position to make the pension adjustment orders in the absence of information from them'. ${ }^{111}$ The challenges faced by lay litigants seeking access to pension adjustment orders was also highlighted in O'Shea's study. ${ }^{112}$

\section{Where to next? Possible avenues for reform}

Based on the foregoing, it is clear a multifaceted approach needs to be taken to address the issues endemic in pension-sharing on divorce in Ireland. At a fundamental level, the difficulties highlighted in $F v M$ speak to the weaknesses associated with the adoption of an unpredictable, highly discretionary, ancillary relief regime. The uncertainty created by the regime has knock-on effects in terms of promoting litigation and, where such litigation is not pursued (perhaps, particularly, due to financial constraints), can contribute to increasing the vulnerability of financially weaker spouses to potentially disadvantageous settlements. To address these shortcomings, and as part of a wider reform of the Irish approach to ancillary relief provision, ${ }^{113}$ it is clear that a more predictable approach needs to be adopted to identify the designated benefit - the share of the pension that is being redistributed to the non-member. Although organisations

108 Pension Advisory Group (n 2) 35.

109 Ibid 37.

110 The appellant alleged that one representative of the trustees who attended the Supreme Court for one day in earlier litigation charged $€ 15,790$ for their services. It is unclear whether the fees were associated with a trustee's appearance in relation to earlier litigation where the appellant husband tried to prevent them 'unnecessarily' making a transfer of $50 \%$ of the funds (see [35]-[36]) or whether they related to the trustee's presence 'assisting the courts as to how monies could be released from the fund for the purposes of making a pension adjustment order' (see [5]). It is also unclear as to why a paper report was not sufficient.

$111 F v M$ (n 5) at [36]. In England and Wales, Woodward (with Sefton) (n 2) noted 'pension orders are hard to achieve fairly or at all without legal and/or expert advice. Even family lawyers and judges benefit from expert help on pensions except in the simplest of cases.' However, see recommendations in Pension Advisory Group (n 2) 10 and Part 6 for so-called 'pensions on divorce experts' (PODEs) who can act as Single Joint Experts (SJEs) instructed by both parties.

112 See, for example, O'Shea (n 4) 207 and 279. This issue has also received increased attention in England and Wales, see Hitchings et al (n 2) 127.

113 Note various proposals for reform which seek to bring greater certainty and predictability to ancillary relief provision, particularly property division, have been presented in Ireland. O'Sullivan (n 20) presented a detailed proposal for reform, adopting a rules-based discretion approach. Louise Crowley, 'Irish Divorce Law in a Social Policy Vacuum - From the Unspoken to the Unknown' (2011) 33(3) Journal of Social Welfare and Family Law 227 advocated for the judicial development of clear principles. Lucy-Ann Buckley 'Matrimonial Property and Irish Law: A Case for Community' (2002) 53 Northern Ireland Law Quarterly 39 argues for the adoption of a community of property approach. 
such as the National Women's Council of Ireland have advocated for compulsory pension-splitting, presumably on a $50 / 50$ basis, ${ }^{114}$ a more nuanced approach, ensuring some discretion remains in the hands of the judiciary, may be preferable and more politically palatable. Pursuant to the Family Law Act 2011 in British Columbia, for example, the legislation applies a presumption that parties share the pension benefits accrued during the marriage, with the benefits not arising until the parties retire. ${ }^{115}$ This presumption can be rebutted where it would give rise to 'serious unfairness'. A similar approach could be adopted in Ireland. ${ }^{116}$ Once the reckonable period is established, the presumptive equal share could then be used for earmarking, pension-splitting or valued to facilitate a reconfiguration of the overall package agreed if so desired. ${ }^{117}$ Such reform - if combined with a more transparent and reflective approach to the valuation of pension assets in the first instance - would not only promote greater consistency and certainty but would also ensure that settlements could take place under the shadow of the law and alleviate some of the vulnerability suffered by financially weaker spouses.

However, while we await such reform we can continue to make progress. First, the influential role that the Irish courts can have in addressing some of the difficulties highlighted, in particular the lack of certainty, ought to be reiterated. Having identified similar issues in England and Wales, Woodward noted the need for greater 'guidance and clarification from case law' on issues of frequent dispute as well as 'some basic guidelines' on, for example, the valuation of offsets. ${ }^{118}$ She recommended that there ought to be 'a standard requirement to spell out the reasoning and objectives behind any proposed order, to include the basis of any pension share, whether a pension offset is proposed and if so how it has been calculated, and what the overall net effects are'. ${ }^{119}$ Acknowledging that ' $[t]$ his might add a little time to each case', she nevertheless felt it 'would help concentrate minds and result in greater understanding, clarification and longer term benefits for parties, practitioners and judges'.120 The need to encourage such judicial engagement would appear equally important in Ireland and could certainly play an important role in addressing many of the weaknesses identified.

Second, although the then Pensions Ombudsman Paul Kenny noted in 2007 that the relevant sections of the Acts were 'drafted in a reasonably straightforward way', 121 various technical weaknesses of the legislation have been highlighted, in particular by Cahill and Dixon, and have certainly added to the perceived complexity of the regime. ${ }^{122}$ These could be remedied with minimal tweaking, simplifying the scheme and eliminating

114 The National Women's Council of Ireland (n 46) 57 notes: 'An alternative approach to achieve gender pension equity is to statutorily require pension splitting. With increased levels of divorce and remarriage it has become necessary to have a fair way of rectifying inequality in pension provision between both partners in a marriage. In Germany, Netherlands and Switzerland it is mandatory to split equally the pensions of both spouses.'

115 This largely replicates the former approach applied under Part 6 of the Family Relations Act 1996, see British Columbia Law Institute (n 1). It was concluded that overall the pension division provisions of the 1996 Act worked well and as a result were carried into the 2011 Act with no major amendments. See also the Ministry of Justice (n 1).

116 For more, see O’Sullivan (n 20).

117 Cahill and Dixon (n 4) 72 note that calculating the transfer amount in a 'defined contribution scheme is reasonably straightforward'. Although they also note that with a defined benefit scheme calculating the transfer amount is 'more complicated', it is possible. For more on valuation issues, see above.

118 Woodward (with Sefton) (n 2) 191.

119 Ibid.

120 Ibid.

121 Paul Kenny, 'Pensions? No Need to Panic' (2007) 1(2) Family Law Matters 43, 43.

122 Cahill and Dixon (n 4) ch 8. 
perceived flaws. The difficulties associated with the failure to include provision for pension blocking orders where no pension adjustment is ordered, as discussed above, must be addressed. ${ }^{123}$ Calls have been made for reform to address the fact that, at present, contingent benefit pension adjustment orders cannot be varied or discharged. ${ }^{124}$ The 12-month limitation period for seeking a pension adjustment order in respect of contingent benefits has also been criticised as an 'arbitrary rule' and could easily be remedied. ${ }^{125}$

Third, it would appear that greater effort needs to be made to educate and support practitioners and divorcing couples alike in dealing with pensions as part of the ancillary relief process. As former Ombudsman Kenny explained over a decade ago:

... when it comes to drafting and actually implementing PAOs, the provisions of Murphy's Law seem to apply with greater force than those of either of the [Family Law Acts]. I find this mysterious and distressing: mysterious, because it shouldn't be that difficult; distressing, because the results of error can be catastrophic for the intended beneficiary. I believe that some difficulties arise just because the word 'pension' is involved, a word that seems to generate panic in otherwise sane and sober individuals. ${ }^{126}$

Although some support has been provided in the interim, for example by the Law Society of Ireland through the publication of its sample pension adjustment order, more is required. ${ }^{127}$ Indeed, the perception of practitioners as to difficulty of dealing with pensions on divorce is not unique to Irish practice. High levels of confusion were also recently reported in England and Wales. Given the scope of her research study, Woodward linked this confusion to poorer outcomes. ${ }^{128}$ As a result, she too emphasised the importance of education initiatives:

The findings imply that if there is to be any improvement in the outcome of cases involving pensions, more public education on pensions is required, more training for the divorce lawyers, including on their qualifying courses, and some compulsory pensions training with options for more specialised training for the judiciary. ${ }^{129}$

As well as focusing on developing the competence and confidence of practitioners in drafting effective pension adjustment orders, such education initiatives could also play an important role in better ensuring full disclosure in relation to pensions. Kenny noted that although, when asked about pension entitlements, scheme trustees must provide this information in line with the Guidelines under the Pensions Act 1990, '[s]ometimes the information furnished is inaccurate or incomplete'. ${ }^{130}$ As a result the importance for

123 As Horgan (n 92) notes: 'It should surely be possible to attain a pension blocking order preventing future pension adjustment without having to give 0.01 per cent of the pension over 24 hours to the non-pension member. Other technical nightmares no doubt await unsuspecting practitioners on the pensions area when these orders fall to be implemented by the pension trustees.' Kenny (n 121) 45 also noted this is 'a clumsy device, which increases the scope for error'. For different practical solutions, see Cahill and Dixon (n 4) 124.

124 Cahill and Dixon (n 4) 125-26. They note at 128 that such orders can be varied for qualified cohabitants under the 2010 Act.

125 Ibid 125.

126 Kenny (n 121) 43. He provided numerous examples of bad practice in drafting pension adjustment orders.

127 Cahill and Dixon (n 4) also provide sample orders, see ch 9. British Columbia Law Institute provides accessible information for practitioners and lay people alike, see <http://www.bcli.org/wordpress/wpcontent/uploads/2017/03/March-2017-Questions-and-Answers-on-Pension-Division-Final.pdf.>

128 Woodward (with Sefton) (n 2) 6.

129 Ibid 191.

130 Kenny (n 121) 45. 
practitioners 'to be familiar with all the relevant disclosure requirements to ensure all the relevant information is provided in advance of the case' has been reiterated. ${ }^{131}$

In this context, the 2019 publication in England and Wales of $A$ Guide to the Treatment of Pensions on Divorce presents an interesting template for Ireland. ${ }^{132}$ It aims to help practitioners, financial experts and judges to understand the issues in relation to pensions, draw attention to pitfalls and provide a 'good practice guide for legal practitioners and experts involved in these cases'. 133 Notwithstanding its non-binding nature, the production of such a report for Ireland could certainly go some way towards achieving greater consistency in how the wealth held in pensions on divorce is addressed and the basic understanding necessary for that to occur.

Admittedly, these proposals will not represent a silver bullet and will not cure all the ills associated with the redistribution of wealth held in pensions on divorce. They will not, for example, address the many challenges faced by lay litigants. Whether the obstacles for this latter category of stakeholders can ever be eradicated in the context of ever more complex pension funds remains doubtful. However, these proposals would go some way, at a practical level, in addressing many of the main issues highlighted by reducing the uncertainty inherent in the regime, streamlining the legislative framework and inching Irish ancillary relief provision towards better practice.

\section{Conclusion}

The Department of Justice and the Pensions Board undertook a review of the pensions provisions of the Family Law Acts in 2001. ${ }^{134}$ Yet, despite this, no report was made publicly available following the review and no reform ever came to fruition. To the contrary, many of the weaknesses of the 1995 and 1996 Acts were repeated in the Civil Partnership and Certain Rights and Obligations of Cohabitants Act 2010 with even more confusion and complexity added. ${ }^{135}$ Although it was reported in 2015 that the Department of Justice had indicated that there were 'continued plans' to amend family law legislation in respect of pensions, ${ }^{136}$ these too have failed to materialise.

While the shortcomings of the law in this area undoubtedly affect all parties involved, it remains an unfortunate reality that these effects often retain a gendered dimension. As Joanna Miles and Emma Hitchings recently explained albeit in relation to England and Wales:

. . . many women are still less able than most men to deal alone with the economic shock of divorce: a combination of socio-economic factors and the division of functions within many marriages often leaves wives with lower earning capacity, lower capital resources and lower pension ... savings than their husbands ... 137

The research conducted in Ireland to date appears to indicate a similar reality on this side of the Irish Sea. In this context, any weaknesses in the law or practice which affect such valuable assets must be addressed.

131 Cahill and Dixon (n 4) 130. See also O'Shea (n 4) 198. Hitchings et al (n 2) 99 note challenges with disclosure in relation to pensions in England and Wales. Woodward (with Sefton) (n 2) 191 recommended '[i]mproved standards for financial disclosure'.

132 Pension Advisory Group (n 2).

133 Ibid 10.

134 Geoffrey Shannon, Hilary Walpole and Eleanor Kiely, Maintenance, Pensions and Taxation in Family Law Proceedings (Roundhall 2001).

135 Cahill and Dixon (n 4) 127.

136 Ibid 123.

137 Miles and Hitchings (n 2) 43-44. 
Although it has been pointed out that it is clearly intended that [pension adjustment orders] should not merely be granted as a matter of course in every case'138 - and notwithstanding that, to quote former Pensions Ombudsman Kenny, some family law practitioners and judges 'regard pension adjustment orders as the bane of their lives'139 such orders are an important tool available in ensuring 'proper provision' on marital breakdown under Irish law. Indeed, even where (or, perhaps, particularly where) pension adjustment orders are not sought or granted, it is of the utmost importance that there is clarity as to how pensions are valued, how the value held in such assets is accounted for in any provision made and how any offset has been reached.

There are various weaknesses which beset the Irish approach to ancillary relief provision on relationship breakdown. ${ }^{140}$ To date, however, the challenges pertaining to pensions and pension adjustment orders have attracted little academic or public attention. It is to be hoped that, going forward, greater consideration will be afforded to these assets and that the legislature, judiciary and professional bodies are alive to their own role in ensuring best practice in the redistribution of wealth held in pensions on divorce in Ireland.

138 Cahill and Dixon (n 4) 125.

139 Kenny (n 121) 45. He added these sentiments were also 'shared by pension managers, trustees and scheme administrators'.

140 See O’Sullivan (n 20); Crowley (n 113); Buckley (n 113). 
